\title{
Effect of yacon syrup on blood lipid, glucose and metabolic endotoxemia in healthy subjects: a randomized, double-blind, placebo-controlled pilot trial
}

\author{
Ana Paula DIONÍSIO ${ }^{1 *}$ (D), Maria de Fátima Gomes da SILVA², Antônio Augusto Ferreira CARIOCA ${ }^{3}$, \\ Lia Silveira ADRIANO ${ }^{3}$, Fernando Antônio Pinto de ABREU ${ }^{1}$, Nedio Jair WURLITZER ${ }^{1}$, \\ Claudia de Oliveira PINTO $^{1}$, Dorasilvia Ferreira PONTES ${ }^{2}$
}

\begin{abstract}
We investigate the impact of yacon syrup consumption on glycemic, lipid and metabolic endotoxemia in healthy subjects. Thus, 32 healthy were randomized into two groups that consumed $40 \mathrm{~g}$ of yacon syrup/day ( $=8.74 \mathrm{~g}$ FOS/day) or a placebo, for 2-weeks. Anthropometric assessments, gastrointestinal effects, glycemic and lipid profile, and LPS were performed at the beginning and at the end of the study. The results obtained shown that the 2-weeks consumption of yacon syrup does not promote serum LPS alteration in healthy volunteers. Moreover, the glycemic and lipid profile were also similar between the groups before and after the intervention. Yacon syrup did not affect blood lipid, glucose or metabolic endotoxemia. However, it is possible that positive effects of yacon syrup will turn evident only in a long-term intervention. Further studies are needed to assess the long-term effect of yacon syrup consumption, and its use in obese and diabetic individuals.
\end{abstract}

Keywords: Smallanthus sonchifolius; fructooligosaccharides; prebiotics; lipopolysaccharides.

Practical Application: In this work we evaluate the effects of a prebiotic product (yacon syrup) on human healthy.

\section{Introduction}

Yacon [Smallanthus sonchifolius (Poepp. et Endl.) H. Robinson] is a perennial herbaceous plant of the family Asteraceae, native to the Andean regions of South America and cultivated in other countries, such as Brazil (Castro et al., 2017). They store their carbohydrates in the form of $\beta$-1,2-fructooligosaccharides (FOS), which are able to resist the hydrolysis of enzymes from the upper gastrointestinal tract (Delgado et al., 2013), and selectively stimulate the growth of bifidobacteria, a gram-positive microorganism that play a regulatory role in the colon by inhibiting the growth of putrefactive bacteria (Caetano et al., 2016). Thus, FOS are considered as a prebiotic, which was recently defined as "[...] a substrate that is selectively utilized by host microorganisms conferring a health benefit" (Gibson et al., 2017, p. 493). The dairy foods products are the most famous carrier of prebiotics, such as reduced-fat bioyoghurt containing either short- or long-chain inulin (Teimouri et al., 2018), reduced-fat Labneh cheese with inulin and $\beta$-glucan fibre-based fat replacer (Aydinol \& Ozcan, 2018), and milk-sour cherry juice mixture containing inulin and hydrocolloid (Dabour et al., 2019). So, the use of yacon as a source of prebiotic compounds may be interesting to provide an alternative way to functionalize foods and beverages, including dairy products.

Several preclinical and clinical trials support the idea of intestinal bacteria involvement in host metabolism and potential prevention of prebiotic interventions (Nakamura \& Omaye, 2012). According to these trials, FOS intake favors the modulation of the microbiota, stimulating the growth of health-promoting microorganisms and reducing pathogenic bacteria populations. Furthermore, the short chain fatty acids (SCFA), such as butyrate, propionate, and acetate - the endproducts of FOS fermentation by the intestinal microbiota - act as substrates or signaling molecules in the regulation of the glucose homeostasis and lipid metabolism. In this sense, the glycemic levels and body weight, for instance, can be reduced (Caetano et al., 2016; Kim et al., 2014; Nakamura \& Omaye, 2012; Wanders et al., 2011). In addition, specific intestinal bacteria (gram negative) seem to serve as lipopolysaccharide (LPS) sources and increased intestinal permeability and to play a role in systemic inflammation (Nakamura \& Omaye, 2012; Kim et al., 2014). Interestingly, the number of bifidobacteria was inversely correlated with the development of glucose intolerance and LPS level (Delzenne et al., 2011, 2013). Cani et al. (2007) were the authors who first proposed that a gram-negative bacterial outer membrane component known as lipopolysaccharide (LPS) was responsible for early onset of inflammation, insulin resistance, obesity, and diabetes. The authors observed that supplementation of high-fat diet (HFD) in mice for 4-weeks increased the plasma LPS levels by 2 to 3 times than those of control animals and called it "metabolic endotoxemia".

Studies investigating the effects of prebiotics on metabolic parameters and inflammation in human showed different relevant findings (Costa et al., 2012, 2015), therefore, additional research 
is required to establish a more clear relationship between them. Focusing on studies using healthy subjects, Van Dokkum et al. (1999) showed no modifications of plasma lipids and glucose absorption, after the consumption of $15 \mathrm{~g}$ of FOS/d after three weeks. In contrast, Brighenti et al. (1999) found a striking reduction in the triglycerides (TG) levels and a moderate decrease in plasma cholesterol after the consumption of $9 \mathrm{~g}$ inulin/d for 4 weeks; and Letexier et al. (2003) observed a decrease in plasma TG ( 16\%) in subjects ingesting $10 \mathrm{~g}$ inulin/d for six weeks. Some studies indicated that xylo-oligosaccharide (XOS) in combination with inulin modulates both the intestinal environment and immune status in healthy subjects (Lecerf et al., 2012). Nilsson et al. (2008) shows that including indigestible carbohydrates in the evening meal of healthy subjects improves glucose tolerance, lowers inflammatory markers, and increases satiety after a subsequent standardized breakfast.

It can be observed that there is evidence that relates the consumption of prebiotics with beneficial effects in humans. However, the understanding of the prebiotic relationship with glycemic, lipid and endotoxemia in human subjects is still scarce, and the results are contradictory and based, mostly, in the effect of isolated compounds (FOS, XOS, inulin, and others) and not as a complex matrix food, such as yacon syrup. The yacon syrup represents an alternative and convenient product to human diet consumption, presents high levels of bioactive compounds, especially FOS (Silva et al., 2018a), and is obtained from a process which comprises an acid and enzymatic treatment, followed by microfiltration and concentration (Silva et al., $2018 \mathrm{~b})$. After a short and medium-term intervention of this yacon syrup in healthy subjects $(\sim 8.74 \mathrm{~g}$ FOS/d), the results showed important sex-based differences in appetite responses to foods, with effects observed only in a medium-term intervention (Silva et al., 2017). However, its metabolic effects are still unexplored and are an important step in positioning it as a nutraceutical product.

Therefore, this pilot study aimed to evaluate the impact of yacon syrup consumption on glycemic, lipid and endotoxemia (lipopolysaccharides, LPS) in healthy subjects through a randomized 2 -weeks placebo-controlled intervention study.

\section{Materials and methods}

\subsection{Yacon syrup preparation}

The yacon syrup was produced in a pilot plant by Embrapa Tropical Agroindustry (Fortaleza - Ceara - Brazil). Initially, after acid treatment of the yacon (Dionisio et al., 2013), the juice is extracted from the root, treated with Celluclast ${ }^{\circledR} 1.5 \mathrm{~L}$ and Pectinex ${ }^{\circledR}$ Ultra SP-L (500 ppm of each enzyme, at $35^{\circ} \mathrm{C}$, $175 \mathrm{rpm}$, for 2 hours), and filtered in microfiltration system (Silva et al., 2018b). Thus, the clarified juice was concentrated under vacuum $\left(<60^{\circ} \mathrm{C}\right)$ until it reached $71^{\circ}$ Brix, and $\mathrm{pH}$ 3.7. The syrup was portioned into $40 \mathrm{~g}$ packs (corresponding to $8.74 \mathrm{~g}$ of FOS, $71.66 \mathrm{kcal}$ or $301.61 \mathrm{~kJ}$ ) and stored at $5^{\circ} \mathrm{C}$. The placebo was corn syrup, diluted up to $71^{\circ} \mathrm{Brix}$ with water, acidified with $0.1 \%$ citric acid (final $\mathrm{pH} \sim 3.7$ ) and added of $0.018 \%$ caramel colorant. The placebo was portioned into $40 \mathrm{~g}$ and stored at $5{ }^{\circ} \mathrm{C}$, as well as the yacon syrup. The fructooligosaccharides
(FOS) was determined using a Fructan Assay Procedure AOAC Method 999.03, AACC Method 32.32 (Megazyme International Ireland Ltda, 2018).

\subsection{Study design and subjects}

Subjects were studied over a 2 -weeks period in a double-blind placebo-controlled experiment. The volunteers were randomly assigned to two groups. Group 1 received yacon syrup containing an intake level of $8.74 \mathrm{~g}$ FOS/day and group 2 included volunteers who received the placebo syrup. The randomization plan was conducted at the website (Randomization, 2017). The study protocol was approved by the Research Ethics Committee of the State University of Ceará (UECE) (no 56094516.4.0000.5534), according to the National Commission of Ethics in Research of the Ministry of Health (CONEP/MS). All volunteers signed a free and informed consent form prior to the intervention. Inclusion criteria were included in the study: both sexes; between 20 and 59 years of age; do not present chronic self-reported diseases; have a body mass index greater than $18.5 \mathrm{~kg} \mathrm{~m}^{-2}$; not being in current use and in the last 30 days of hypoglycemic, lipid-lowering and anti-inflammatory drugs; not to participate in another clinical trial; not present current consumption and in the last 30 days of fiber supplementation and FOS. Exclusion criteria were: pregnancy; current smoker or in the last 30 days; daily ethanol consumption greater than $30 \mathrm{~g}$ for men and $15 \mathrm{~g}$ for women; use of hypoglycemic, lipid-lowering, antibiotic and anti-inflammatory drugs during the intervention.

Thirty out of a total of 32 volunteers completed this study with good compliance. The study was completed by 30 volunteers, distributed in the yacon syrup $(n=15)$ and placebo groups $(\mathrm{n}=15)$ (see Figure 1$)$. The volunteers consumed daily $40 \mathrm{~g}$ of yacon syrup or $40 \mathrm{~g}$ of placebo in the morning, along with foods commonly consumed or alone. The volunteers were instructed not to change their eating habits and lifestyle during the intervention.

\subsection{Demographic and anthropometric evaluation}

At the beginning of the study, all the volunteers were interviewed by a structured form, containing data referring to sex, age, race (self-referenced) and health status. A digital scale (Tanita ${ }^{\circledR}$ HD-313) was used to evaluate body weight, with a capacity of $150 \mathrm{~kg}$, a sensitivity of 100 grams. The individuals were weighed in a lightweight and barefoot clothing, positioned in an upright posture, with the feet fully positioned on the platform of the scale, with arms along the body and looking at the horizon. To measure the height, was used a wall stadiometer (Seca $208^{\circledR}$ ) with scale in millimeters. Measurement of waist circumference was performed with the tape measure positioned on the midpoint between the last costal arch and the iliac crest of the standing subject, with the reading made at the time of expiration. These data were collected by previously trained field researchers at the beginning and end of the study. Weight and height were used to calculate body mass index $\left(\mathrm{BMI}, \mathrm{kg} \mathrm{m}^{-2}\right.$ ), as well as waist circumference (WC, $\mathrm{cm}$ ) and waist-hip ratio (WHR). 


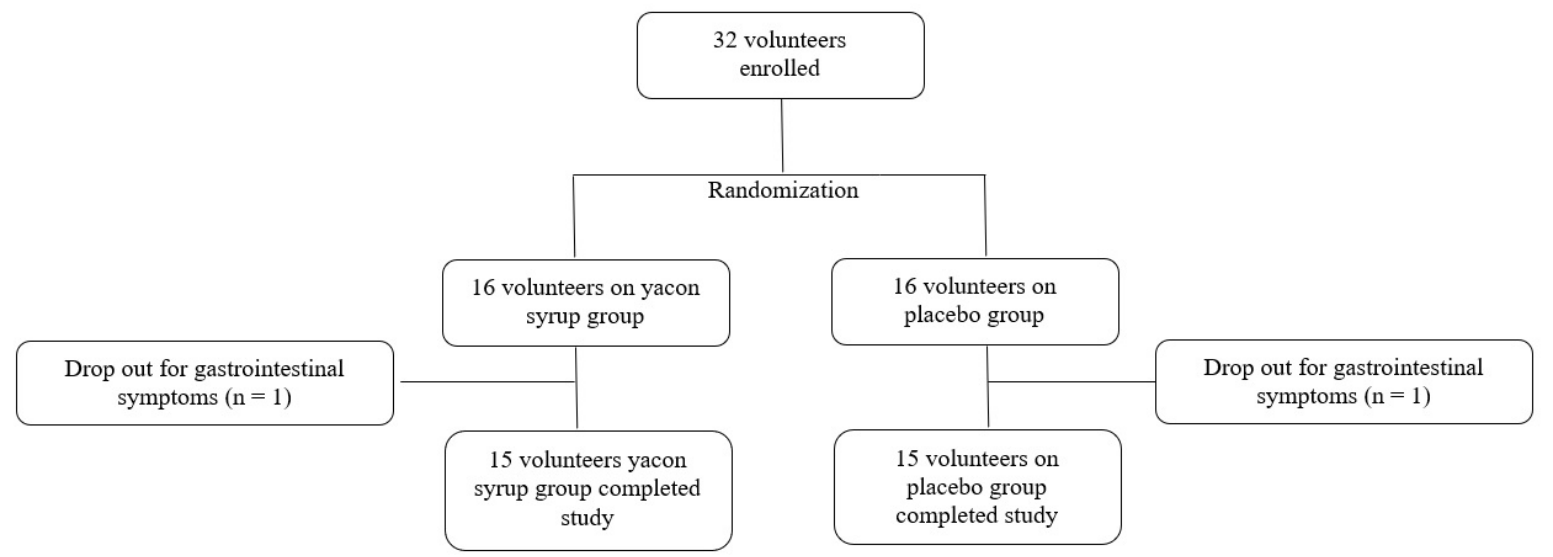

Figure 1. Flow diagram of participants.

\subsection{Blood sampling}

At the beginning of the study and on day 15, the blood samples were collected from volunteers who fasted overnight $(12 \mathrm{~h})$, and placed in tubes containing EDTA. Samples were transferred to sterilized centrifuge tubes and centrifuged for $10 \mathrm{~min}$ at $3000 \mathrm{~g}$ for serum separation. All serum and plasma aliquots for the biochemical determinations were kept frozen at $-80{ }^{\circ} \mathrm{C}$ until analysis.

\subsection{Biochemical measurements}

The concentrations of total cholesterol, serum HDL cholesterol and triacylglycerol were analyzed using enzymatic colorimetric methods. The fasting glycemia was analyzed by enzymatic UV method (hexoquinase). The cholesterol content associated with LDL was estimated using Friedewald's formula (Friedewald et al., 1972). Serum plasma insulin was measured by chemiluminescence. Apolipoproteins B (Apo-B100) was determined by turbidimetric immunoassay method (Autokits APOB100, Randox Chemicals USA Inc., Richmond, VA, USA). The analysis of lipopolysaccharides - LPS was performed using Enzyme-Linked Immunosorbent Assay (ELISA) and ultra-sensitive C-reactive protein (hsCRP) was analyzed using Immuno-turbidimetric method, commercial kits from MyBioSource. All the biochemical analyzes were performed in serum before $\left(t_{0}\right)$ and after the intervention $\left(t_{15}\right)$.

\subsection{Evaluation of gastrointestinal effects}

Potential adverse effects including flatulence, bloated feeling, abdominal rumbling and abdominal pain were monitored daily using a diary. Alterations related to constipation were evaluated through a constipation scale (minimum score: 0 - normal, maximum score: 30 - severe constipation), according to a questionnaire proposed by Agachan et al. (1996).

\subsection{Data analysis}

An intention-to-treat analysis was performed. The data were compared by Student t-test or chi-square. The data are given as means \pm standard deviation or with their $95 \%$ confidence intervals, after analysis of covariance (ANCOVA). The statistical analyzes were performed with the SPSS package version 20.0. $\mathrm{P}$ values of $<0.05$ were considered statistically significant.

\section{Results and discussion}

Yacon syrup is a product obtained by enzymatic treatment, followed by microfiltration and vacuum concentration until it reaches a level of $71^{\circ} \mathrm{Brix}$ (Silva et al., 2018a). This product contains high levels of FOS and phenolic compounds derived from quinic and trans-cinnamic acids (such as chlorogenic acid), and presents some mineral elements, such as $\mathrm{K}, \mathrm{Ca}$ and $\mathrm{P}$, and essential amino acids, such as tryptophan, valine, and threonine (Silva et al., 2018b). Moreover, we demonstrated in previous work, that yacon syrup administered as a diet supplement in women individuals showed a positive effect on appetite after a 2-week period of intervention (Silva et al., 2017). However, these effects were not observed when the yacon syrup was acute administered.

The effects of yacon syrup in colonic transit time of healthy volunteers (Geyer et al., 2008) and in biochemical parameters and appetite of obese and slightly dyslipidemic pre-menopausal women (Genta et al., 2009) were reported in the literature. These findings raise the interesting possibility of investing the effects of yacon syrup on human health. However, to the author's knowledge, the effects on blood lipid, glucose and metabolic endotoxemia in healthy subjects were still unexplored.

In this sense, in the present study, we evaluate the effect on blood lipid, glucose and metabolic endotoxemia of the yacon syrup consumption, in healthy volunteers. The yacon syrup has $22 \%$ of FOS, corresponding to a daily portion of $8,74 \mathrm{~g} \mathrm{FOS} / \mathrm{d}$, for each volunteer, for 2-weeks. Thirty-two volunteers were initially included in the study, but two dropped out and were not replaced. Thirty subjects completed the study (retention rate of 94\%). The baseline characteristics of these subjects are presented in Table 1 and have shown no differences between the intervention groups. Body mass index (BMI) in both groups $\left(\sim 25 \mathrm{~kg} / \mathrm{m}^{2}\right)$ was similar. No change was observed in the placebo group for WC, BMI, and WHR after the intervention period (see Table 2). 
At the end of the study, adverse effects, such as flatulence, abdominal rumbling, bloated feeling, and cramps, were reported in the yacon syrup on the first days during the treatment. None of these were considered serious or harmful to health, and they subsided with adaptation over time. The literature reports that FOS will be tolerated and do not cause gastrointestinal problems when taken at a minor dose of $15 \mathrm{~g}$ daily (Ojansivu et al., 2011; Scheid et al., 2014; Williams \& Jackson, 2002). Genta et al. (2009) report significant gastrointestinal adverse effects such as diarrhea, severe abdominal, distention, flatulence, and nausea when the patients consumed yacon syrup containing $20 \mathrm{~g}$ FOS/d. In contrast, the group treated with yacon syrup at a level intake of $10 \mathrm{~g} \mathrm{FOS} / \mathrm{d}$ went through the whole experimental period with no difficulties.

Results from the biochemical markers for glucose and lipid metabolism at baseline and post-intervention for both groups are summarized in Table 3. At baseline, there were no

Table 1. Pre-treatment characteristics of subjects scheduled to participate in this study.

\begin{tabular}{lccc}
\hline \multicolumn{1}{c}{ Variables } & Yacon yrup $(\mathrm{n}=15)$ & Placebo $(\mathrm{n}=15)$ & $\mathrm{p}^{*}$ \\
\hline Age, years & $41.7 \pm 8.9$ & $40.1 \pm 8.0$ & 0.585 \\
Female $(\%)^{* *}$ & $10.0(66.7 \%)$ & $11.0(68.8 \%)$ & 1.000 \\
Body weight $(\mathrm{kg})$ & $69.1 \pm 14.0$ & $71.2 \pm 16.4$ & 0.712 \\
WC $(\mathrm{cm})$ & $82.9 \pm 8.2$ & $82.9 \pm 11.7$ & 0.999 \\
BMI $\left(\mathrm{kg} \mathrm{m}^{-2}\right)$ & $25.3 \pm 3.3$ & $25.0 \pm 4.8$ & 0.834 \\
WHR & $0.8 \pm 0.1$ & $0.8 \pm 0.1$ & 0.741 \\
Glucose $\left(\mathrm{mg} \mathrm{dL}^{-1}\right)$ & $85.0 \pm 6.0$ & $84.0 \pm 7.0$ & 0.694 \\
Insulin $\left(\mu \mathrm{UL} \mathrm{m}^{-1}\right)$ & $9.2 \pm 4.6$ & $7.8 \pm 3.6$ & 0.337 \\
Total cholesterol $\left(\mathrm{mg} \mathrm{dL}^{-1}\right)$ & $191.0 \pm 22.0$ & 0.967 \\
HDL-C $\left(\mathrm{mg} \mathrm{dL}^{-1}\right)$ & $192.0 \pm 27.0$ & $56.0 \pm 13.0$ & 0.646 \\
LDL-C $\left(\mathrm{mg} \mathrm{dL}^{-1}\right)$ & $54.0 \pm 13.0$ & $112.0 \pm 25.0$ & 0.961 \\
Apo B $\left(\mathrm{mg} \mathrm{dL}^{-1}\right)$ & $111.0 \pm 21.0$ & $91.0 \pm 16.6$ & 0.633 \\
Triacylglycerols $\left(\mathrm{mg} \mathrm{dL}^{-1}\right)$ & $93.7 \pm 14.9$ & $117.0 \pm 60.0$ & 0.555 \\
LPS $($ pg mL & & \\
hsCRP $\left(\mathrm{mg} \mathrm{dL}^{-1}\right)^{\#}$ & $132.0 \pm 81.0$ & $15.3 \pm 6.4$ & 0.235 \\
Constipation scale, ponctuation & \\
\hline
\end{tabular}

\#Values expressed in median (minimum and maximum values); ${ }^{\star}$ Probability, no significant differences in a Mann-Whitney Test ( $\left.\mathrm{p}>0.05\right)$; ${ }^{*}$ Expressed in $\mathrm{n}(\%)$. $\mathrm{n}=$ number of volunteers; $\mathrm{WC}=$ waist circumference; $\mathrm{BMI}=$ body mass index; WHR = waist-hip ratio; LDL-C = low-density lipoprotein; HDL-C = high-density lipoprotein; Apo B = Apo lipoprotein B; LPS = lipopolysaccharides; hsCRP = Highly sensitive C-reactive protein.

Table 2. Anthropometric parameters before the test (baseline, $\mathrm{t}_{0}$ ) and after 2-weeks $\left(\mathrm{t}_{15}\right.$ ) of treatment (yacon syrup or placebo).

\begin{tabular}{|c|c|c|c|c|c|c|}
\hline \multirow{2}{*}{ Variables ${ }^{\#}$} & \multicolumn{2}{|c|}{ Yacon syrup $(\mathrm{n}=15)$} & \multicolumn{2}{|c|}{ Placebo $(\mathrm{n}=15)$} & \multicolumn{2}{|c|}{ Mean difference* } \\
\hline & Baseline & 2-weeks & Baseline & 2-weeks & $\beta$ & CI 95\% \\
\hline Body weight (kg) & $69.1 \pm 14.0$ & $69.2 \pm 14.0$ & $71.2 \pm 16.4$ & $71.2 \pm 16.4$ & 0.07 & $-0.26 ; 0.40$ \\
\hline $\mathrm{WC}(\mathrm{cm})$ & $82.9 \pm 8.2$ & $82.3 \pm 8.0$ & $82.9 \pm 11.7$ & $82.5 \pm 12.3$ & -0.16 & $-0.98 ; 0.66$ \\
\hline $\mathrm{BMI}\left(\mathrm{kg} \mathrm{m}^{-2}\right)$ & $25.3 \pm 3.3$ & $25.3 \pm 3.3$ & $25.0 \pm 4.8$ & $25.0 \pm 4.8$ & 0.03 & $-0.08 ; 0.15$ \\
\hline WHR & $0.8 \pm 0.05$ & $0.8 \pm 0.05$ & $0.8 \pm 0.06$ & $0.8 \pm 0.07$ & -0.01 & $-0.02 ; 0.01$ \\
\hline
\end{tabular}

${ }^{*}$ Results are expressed as mean \pm standard deviation; ${ }^{*}$ Regression analysis $(\beta$ values and $95 \%$ confidence interval $(\mathrm{CI})$ ). $\mathrm{n}=$ number of volunteers; $\beta=$ regression coefficient; $\mathrm{CI} 95 \%=95 \%$ confidence interval; $\mathrm{WC}=$ waist circumference; $\mathrm{BMI}=$ body mass index; WHR $=$ waist-hip ratio.

Table 3. Clinical parameters related to glycemic, lipid, and endotoxemia before the test (baseline, $\left.t_{0}\right)$ and after 2-weeks ( $\left.t_{15}\right)$ of treatment $($ yacon syrup or placebo).

\begin{tabular}{|c|c|c|c|c|c|c|}
\hline \multirow{2}{*}{ Variables ${ }^{\#}$} & \multicolumn{2}{|c|}{ Yacon syrup $(\mathrm{n}=15)$} & \multicolumn{2}{|c|}{ Placebo $(\mathrm{n}=15)$} & \multicolumn{2}{|c|}{ Mean difference ${ }^{\star}$} \\
\hline & Baseline & 15 days & Baseline & 15 days & $\beta$ & CI 95\% \\
\hline Glucose $\left(\mathrm{mg} \mathrm{dL}^{-1}\right)$ & $85.0 \pm 6.0$ & $87.0 \pm 6.0$ & $84.0 \pm 7.0$ & $86.0 \pm 7.0$ & 0.43 & $-2.62 ; 3.47$ \\
\hline Insulin $\left(\mu \mathrm{U} \mathrm{mL}^{-1}\right)$ & $9.2 \pm 4.6$ & $12.3 \pm 7.5$ & $7.8 \pm 3.6$ & $8.6 \pm 4.3$ & 1.90 & $-0.26 ; 4.06$ \\
\hline Total cholesterol $\left(\mathrm{mg} \mathrm{dL}^{-1}\right)$ & $192.0 \pm 27.0$ & $189.0 \pm 25.0$ & $191.0 \pm 21.0$ & $183.0 \pm 24.0$ & 6.19 & $-3.44 ; 15.82$ \\
\hline $\mathrm{HDL}-\mathrm{C}\left(\mathrm{mg} \mathrm{dL}^{-1}\right)$ & $54.0 \pm 13.0$ & $51.0 \pm 13.0$ & $56.0 \pm 13.0$ & $55.0 \pm 11.0$ & -2.45 & $-5.17 ; 0.27$ \\
\hline LDL-C (mg dL $\left.{ }^{-1}\right)$ & $111.0 \pm 21.0$ & $115.0 \pm 17.0$ & $112.0 \pm 25.0$ & $107.0 \pm 22.0$ & 6.16 & $-1.97 ; 14.29$ \\
\hline Apo B $\left(\mathrm{mg} \mathrm{dL}^{-1}\right)$ & $93.7 \pm 14.9$ & $93.2 \pm 14.5$ & $91.0 \pm 16.6$ & $89.7 \pm 15.9$ & 2.44 & $-4.27 ; 9.15$ \\
\hline Triglycerides $\left(\mathrm{mg} \mathrm{dL}^{-1}\right)$ & $132.0 \pm 81.0$ & $135.0 \pm 96.0$ & $117.0 \pm 60.0$ & $102.0 \pm 56.0$ & 17.84 & $-6.96 ; 42.65$ \\
\hline LPS $\left(p g \mathrm{~mL}^{-1}\right)$ & $12.9 \pm 4.2$ & $15.7 \pm 4.9$ & $15.3 \pm 6.4$ & $15.3 \pm 5.2$ & 1.68 & $-1.39 ; 4.75$ \\
\hline hsCRP $\left(\mathrm{mg} \mathrm{dL}^{-1}\right)$ & $0.2 \pm 0.1$ & $0.2 \pm 0.1$ & $0.4 \pm 0.6$ & $0.5 \pm 0.7$ & -0.15 & $-0.47 ; 0.17$ \\
\hline
\end{tabular}

"Results expressed as mean \pm standard deviation; ${ }^{\star}$ Regression analysis ( $\beta$ values and $95 \%$ confidence interval $(\mathrm{CI})$ ). $\mathrm{n}=$ number of volunteers; $\beta=$ regression coefficient; $\mathrm{CI} 95 \%=95 \%$ confidence interval; LDL-C = low-density lipoprotein; HDL-C = high-density lipoprotein; Apo B = Apo lipoprotein B; LPS = lipopolysaccharides; hsCRP = highly sensitive C-reactive protein. 
significant differences in any biochemical variable between the placebo and the experimental group. Serum levels of glucose, insulin, total, Apo B, HDL, LDL, cholesterol, and triglycerides (TG) were within normal ranges for both groups. Therefore, the yacon syrup supplementation ( 8.74 g FOS/d) ingested by subjects in 2-weeks may have been insufficient to influence the glucose and lipid metabolism, indicating that it need to be tested in higher doses and/or a more extended duration study. Moreover, several papers reports that the effect of prebiotics in glycemic and lipid metabolism are conflicting and inconsistent, especially in healthy subjects (Liu et al., 2017; Kellow et al., 2014; Costa et al., 2012; Beylot, 2005).

Kellow et al. (2014), in a systematic review of randomized controlled trials evaluating the metabolic benefits of dietary prebiotics in human subjects, conclude that the effects of prebiotics on insulin sensitivity, lipids, inflammatory markers and immune function were contradictory. The authors show that the association can be clearly associated with subjective improvements in satiety and reductions in postprandial glucose and insulin concentrations. Liber \& Szajewska (2013), evaluated the effects of inulin-type fructans (ITF) on energy intake and body weight in children and adults, and concluded that the long-term administration of ITF may contribute to weight reduction. Sperry et al. (2018) evaluated the clinical effects of regular consumption of probiotic Minas Frescal cheese on hypertensive overweighed women, and showed an improvement in total cholesterol, low-density lipoprotein-cholesterol, high-density lipoprotein-cholesterol, triacylglycerides, diastolic and systolic pressure, hemoglobin, and hematocrit count of the hypertensive overweighed women. Wanders et al. (2011) show that different types of fiber affect subjective appetite, acute energy intake, long-term energy intake and body weight differently. The authors indicate that additional research (short-term and long-term intervention) is still necessary. More recently, Liu et al. (2017) reviewed the effect of ITF on blood lipid profile and glucose level. The authors have shown that the use of ITF may have benefits for LDL-cholesterol reduction across all study populations, whereas HDL-cholesterol improvement and glucose control were demonstrated only in the type 2 diabetes mellitus group. Thus, the authors conclude that an additional, well-powered, long-term, randomized clinical trials are required for a definitive conclusion. Williams \& Jackson (2002) reviewed the effects of inulin and oligofructose on lipid metabolism, in human studies. The authors observed that the positive outcomes in lipid metabolism were observed more frequently in those studies conducted in subjects with moderate hyperlipidemia. In this sense, the use of yacon syrup supplementation in subjects presenting a low-grade systemic inflammation such as in obesity, metabolic syndrome and/or patients of type 2 diabetes will be considered in further studies.

Yamashita et al. (1984) studied the systemic effects of adding $8 \mathrm{~g} / \mathrm{d}$ FOS for 2 -weeks to the diet of patients with type 2 diabetes mellitus whose serum glucose concentration was uncontrolled. Fasting blood test showed $8 \%$ reduction in serum glucose levels. In contrast, Alles et al. (1999) evaluated the effect of $15 \mathrm{~g} / \mathrm{d}$ FOS for 3-weeks in patients with type 2 diabetes mellitus and showed no significant changes in the glucose levels and lipid concentrations. Additionally, Luis et al. (2011) and Dewulf et al. (2013) showed differences in glucose and lipid metabolism after a 4-week to 3-month consumption of a prebiotic supplemented diet in obese patients.

In healthy subjects, Brighenti et al. (1999) found a striking reduction in the plasma TG levels and a moderate decrease in plasma cholesterol after the consumption of $9 \mathrm{~g}$ inulin/d for 4 weeks; and Letexier et al. (2003) observed a 16\% decrease in plasma TG in subjects ingesting $10 \mathrm{~g}$ inulin/d for 6 weeks. Russo et al. $(2008,2010)$ showed positive effects on lipid and glycemic profile when inulin-enriched pasta was consumed by healthy male subjects for 5-weeks. In contrast, Van Dokkum et al. (1999) showed no modifications of plasma lipids and glucose absorption, after the consumption of $15 \mathrm{~g}$ of FOS/d after three weeks. Luo et al. (1996) showed that the chronic consumption of short-chain FOS decreased basal hepatic glucose production but had no effect on insulin-stimulated glucose metabolism.

Lipopolysaccharide (LPS) or endotoxin is a bacterial cell wall component found predominantly in gram-negative bacteria that stimulates an inflammatory response in a process that increases the levels of tumor necrosis factor $\alpha$ (TNF- $\alpha$ ), a potent inflammatory cytokine linked to obesity and type 2 diabetes (Parnell \& Reimer, 2012). This has been named as metabolic endotoxemia (Cani et al., 2007). Evidence from animal studies has shown that LPS levels negatively correlate with bifidobacteria numbers. Moreover, with a prebiotic treatment, the gut barrier was improved, and the LPS level was reduced (Cani et al., 2009). However, in our study, the effect on LPS after the 2-week consumption of yacon syrup (see Table 3) was not significant.

Significant reductions in circulating lipopolysaccharide (LPS) concentrations after 4-weeks of dietary prebiotic supplementation in healthy subjects were reported by Lecerf et al. (2012). Creely et al. (2007) shows that the endotoxin levels are higher (76\%) in individuals with type 2 diabetes than in healthy individuals. In studies with women with type 2 diabetes, Dehghan et al. (2014) showed a significant decrease in the LPS levels after a 8-week oligofructose-enriched inulin consumption. In a similar study, when women with type 2 diabetes received a daily supplement of $10 \mathrm{~g}$ resistant dextrin for 8 weeks, the LPS level was significantly reduced (Aliasgharzadeh et al., 2015). However, in these papers, the intervention period was longer than that used in our study and focused mainly in type 2 diabetes subjects. Utzschneider et al. (2016) reviewed the mechanisms linking the gut microbiome and glucose metabolism, and examined the role of gut permeability in circulating LPS concentrations. The authors conclude that, although the data in animal models are convincing, more data are needed in humans.

To our knowledge, this is the first study to evaluate the effect of yacon syrup consumption on glycemic, lipid and endotoxemia (lipopolysaccharides, LPS) in healthy subjects. Further studies are needed to understand the beneficial effect of yacon syrup in a long-term intervention, and the effects to specific target populations, such as obesity or diabetes, for example.

\section{Conclusions}

In conclusion, 2-weeks of yacon syrup $(\sim 8.74 \mathrm{~g}$ FOS/d $)$ consumption did not affect blood lipid, glucose or metabolic endotoxemia. However, it is possible that positive effects of yacon 
syrup will turn evident only after a long-term intervention. Further studies are needed to assess the long-term effect of yacon syrup consumption, and its use in obese and diabetic individuals.

\section{Acknowledgements}

We thank all the volunteers who participated in this study. Also, the authors would like to thank the Brazilian Agricultural Research Corporation (EMBRAPA) and the National Council for Scientific and Technological Development $(\mathrm{CNPq})$ for the financial support.

\section{References}

Agachan, F., Chen, T., Pfeifer, J., Reissman, P., \& Wexner, S. D. (1996). A constipation scoring system to simplify evaluation and management of constipated patients. Diseases of the Colon and Rectum, 39(6), 681-685. http://dx.doi.org/10.1007/BF02056950. PMid:8646957.

Aliasgharzadeh, A., Dehghan, P., Gargari, B. P., \& Asghari-Jafarabadi, M. (2015). Resistant dextrin, as a prebiotic, improves insulin resistance and inflammation in women with type 2 diabetes: a randomised controlled clinical trial. British Journal of Nutrition, 113(2), 321-330. http://dx.doi.org/10.1017/S0007114514003675. PMid:27028002.

Alles, M. S., De Roos, N. M., Bakx, J. C., Van De Lisdonk, E., Zock, P. L., \& Hautvast, G. A. (1999). Consumption of fructooligosaccharides does not favorably affect blood glucose and serum lipid concentrations in patients with type 2 diabetes. The American Journal of Clinical Nutrition, 69(1), 64-69. http://dx.doi.org/10.1093/ajcn/69.1.64. PMid:9925124.

Aydinol, P., \& Ozcan, T. (2018). Production of reduced-fat Labneh cheese with inulin and $\beta$-glucan fibre-based fat replacer. International Journal of Food Technology, 71(2), 362-371. http://dx.doi.org/10.1111/14710307.12456.

Beylot, M. (2005). Effects of inulin-type fructans on lipid metabolism in man and in animal models. British Journal of Nutrition, 93(Suppl. 1), S163-S168. http://dx.doi.org/10.1079/BJN20041339. PMid:15877890.

Brighenti, F., Casiraghi, M., Canzi, E., \& Ferrari, A. (1999). Effect of consumption of a ready-to-eat breakfast cereal containing inulin on the intestinal milieu and blood lipids in healthy male volunteers. European Journal of Clinical Nutrition, 53(9), 726-733. http://dx.doi. org/10.1038/sj.ejcn.1600841. PMid:10509770.

Caetano, B., Moura, N., Almeida, A., Dias, M., Sivieri, K., \& Barbisan, L. (2016). Yacon (Smallanthus sonchifolius) as a food supplement: health-promoting benefits of fructooligosaccharides. Nutrients, 8(7), 436-453. http://dx.doi.org/10.3390/nu8070436. PMid:27455312.

Cani, P. D., Neyrinck, A. M., Fava, F., Knauf, C., Burcelin, R. G., Tuohy, K. M., Gibson, G. R., \& Delzenne, N. M. (2007). Selective increases of bifidobacteria in gut microflora improve high-fat-diet-induced diabetes in mice through a mechanism associated with endotoxaemia. Diabetologia, 50(11), 2374-2383. http://dx.doi.org/10.1007/s00125007-0791-0. PMid:17823788.

Cani, P. D., Possemiers, S., Van De Wiele, T., Guiot, Y., Everard, A., Rottier, O., Geurts, L., Naslain, D., Neyrinck, A., Lambert, D. M., Muccioli, G. G., \& Delzenne, N. M. (2009). Changes in gut microbiota control inflammation in obese mice through a mechanism involving GLP-2-driven improvement of gut permeability. Gut, 58(8), 10911103. http://dx.doi.org/10.1136/gut.2008.165886. PMid:19240062.

Castro, A., Vilaplana, F., \& Nilsson, L. (2017). Characterization of a water soluble, hyperbranched arabinogalactan from yacon (Smallanthus sonchifolius) roots. Food Chemistry, 223, 76-81. http://dx.doi. org/10.1016/j.foodchem.2016.12.019. PMid:28069126.
Costa, G. T., Abreu, G. C., Guimarães, A. B. B., Vasconcelos, P. R. L., \& Guimarães, S. B. (2015). Fructooligosaccharide effects on serum cholesterol levels: an overview. Acta Cirurgica Brasileira, 30(5), 366-370. http://dx.doi.org/10.1590/S0102-865020150050000009. PMid:26016937.

Costa, G. T., Guimarães, S. B., \& Sampaio, H. A. C. (2012). Fructooligosaccharide effects on blood glucose. An overview. Acta Cirurgica Brasileira, 27(3), 279-282. http://dx.doi.org/10.1590/ S0102-86502012000300013. PMid:22460261.

Creely, S. J., McTernan, P. G., Kusminski, C. M., Fisher, F. M., Da Silva, N. F., Khanolkar, M., Evans, M., Harte, A. L., \& Kumar, S. (2007). Lipo-polysaccharide activates an innate immune system response in human adipose tissue in obesity and type 2 diabetes. American Journal of Physiology, Endocrinology and Metabolism, 292(3), E740-E747. http://dx.doi.org/10.1152/ajpendo.00302.2006. PMid:17090751.

Dabour, N., Dyab, N., \& Kheadr, E. (2019). Iron fortification of reduced-fat bioyoghurt containing either short- or long-chain inulin. International Journal of Food Technology, 72(2), 229-239. http://dx.doi.org/10.1111/1471-0307.12575.

Dehghan, P., Gargari, B. P., Jafar-Abadi, M. A., \& Aliasgharzadeh, A. (2014). Inulin controls inflammation and metabolic endotoxemia in women with type 2 diabetes mellitus: a randomized-controlled clinical trial. International Journal of Food Sciences and Nutrition, 65(1), 117-123. http://dx.doi.org/10.3109/09637486.2013.836738 . PMid:24059649.

Delgado, G. T., Tamashiro, W. M., Maróstica, M. R. Jr., \& Pastore, G. M. (2013). Yacon (Smallanthus sonchifolius): a functional food. Plant Foods for Human Nutrition, 68(3), 222-228. http://dx.doi. org/10.1007/s11130-013-0362-0. PMid:23709016.

Delzenne, N. M., Neyrinck, A. M., \& Cani, P. D. (2013). Gut microbiota and metabolic disorders: how prebiotic can work? British Journal of Nutrition, 109(Suppl. 2), S81-S85. http://dx.doi.org/10.1017/ S0007114512004047. PMid:23360884.

Delzenne, N. M., Neyrinck, A. M., Bäckhed, F., \& Cani, P. D. (2011). Targeting gut microbiota in obesity: effects of prebiotics and probiotics. Nature Reviews. Endocrinology, 7(11), 639-646. http:// dx.doi.org/10.1038/nrendo.2011.126. PMid:21826100.

Dewulf, E. M., Cani, P. D., Claus, S. P., Fuentes, S., Puylaert, P. G., Neyrinck, A. M., Bindels, L. B., de Vos, W. M., Gibson, G. R., Thissen, J. P., \& Delzenne, N. M. (2013). Insight into the prebiotic concept: lessons from an exploratory, double blind intervention study with inulin-type fructans in obese women. Gut, 62(8), 1112-1121. http:// dx.doi.org/10.1136/gutjnl-2012-303304. PMid:23135760.

Dionisio, A. P., Wurlitzer, N. J., Vieira, N. M., Goes, T. S., Modesto, A. L. G., \& Araujo, I. M. S. (2013). Raiz tuberosa de yacon (Smallanthus sonchifolius): obtenção de extrato com manutenção das propriedades nutricionais e inativação de enzimas de escurecimento (Comunicado Técnico, No. 206). Fortaleza: Embrapa Agroindústria Tropical.

Friedewald, W. T., Levy, R. I., \& Fredrickson, D. S. (1972). Estimation of the concentration of low-density lipoprotein cholesterol in plasma, without use of the preparative ultracentrifuge. Clinical Chemistry, 18(6), 499-502. PMid:4337382.

Genta, S., Cabrera, W., Habib, N., Pons, J., Carillo, I. M., Grau, A., \& Sánchez, S. (2009). Yacon syrup: beneficial effects on obesity and insulin resistance in humans. Clinical Nutrition, 28(2), 182. http:// dx.doi.org/10.1016/j.clnu.2009.01.013. PMid:19254816.

Geyer, M., Manrique, I., Degen, L., \& Beglinger, C. (2008). Effect of yacon (Smallanthus sonchifolius) on colonic transit time in healthy volunteers. Digestion, 78(1), 30-33. http://dx.doi.org/10.1159/000155214. PMid:18781073. 
Gibson, G. R., Hutkins, R., Sanders, M. E., Prescott, S. L., Reimer, R. A., Salminen, S. J., Scott, K., Stanton, C., Swanson, K. S., Cani, P. D., Verbeke, K., \& Reid, G. (2017). Expert consensus document: the International Scientific Association for Probiotics and Prebiotics (ISAPP) consensus statement on the definition and scope of prebiotics. Nature Reviews. Gastroenterology \& Hepatology, 14(8), 491-502. http://dx.doi.org/10.1038/nrgastro.2017.75. PMid:28611480.

Kellow, N. J., Coughlan, M. T., \& Reid, C. M. (2014). Metabolic benefits of dietary prebiotics in human subjects: a systematic review of randomised controlled trials. British Journal of Nutrition, 111(7), 1147-1161. http://dx.doi.org/10.1017/S0007114513003607. PMid:24230488.

Kim, C. H., Park, J., \& Kim, M. (2014). Gut microbiota-derived shortchain fatty acids, T cells, and inflammation. Immune Network, 14(6), 277-288. http://dx.doi.org/10.4110/in.2014.14.6.277. PMid:25550694.

Lecerf, J. M., Dépeint, F., Clerc, E., Dugenet, Y., Niamba, C. N., Rhazi, L., Cayzeele, A., Abdelnour, G., Jaruga, A., Younes, H., Jacobs, H., Lambrey, G., Abdelnour, A. M., \& Pouillart, P. R. (2012). Xylooligosaccharide (XOS) in combination with inulin modulates both the intestinal environment and immune status in healthy subjects, while XOS alone only shows prebiotic properties. British Journal of Nutrition, 108(10), 1847-1858. http://dx.doi.org/10.1017/ S0007114511007252. PMid:22264499.

Letexier, D., Diraison, F., \& Beylot, M. (2003). Addition of inulin to a moderately high-carbohydrate diet reduces hepatic lipogenesis and plasma triacylglycerol concentrations in humans. The American Journal of Clinical Nutrition, 77(3), 559-564. http://dx.doi.org/10.1093/ ajcn/77.3.559. PMid:12600843.

Liber, A., \& Szajewska, H. (2013). Effects of inulin-type fructans on appetite, energy intake, and body weight in children and adults: systematic review of randomized controlled trials. Annals of Nutrition \& Metabolism, 63(1-2), 42-54. http://dx.doi.org/10.1159/000350312. PMid:23887189.

Liu, F., Prabhakar, M., Ju, J., Long, H., \& Zhou, H. W. (2017). Effect of inulin-type fructans on blood lipid profile and glucose level: a systematic review and meta-analysis of randomized controlled trials. European Journal of Clinical Nutrition, 71(1), 9-20. http://dx.doi. org/10.1038/ejcn.2016.156. PMid:27623982.

Luis, D. A., De La Fuente, B., Izaola, O., Conde, R., Gutiérrez, S., Morillo, M., \& Teba Torres, C. (2011). Double blind randomized clinical trial controlled by placebo with an alpha linoleic acid and prebiotic enriched cookie on risk cardiovascular factor in obese patients. Nutrición Hospitalaria, 26(4), 827-833. PMid:22470031.

Luo, J., Rizkalla, S. W., Alamowitch, C., Boussairi, A., Blayo, A., Barry, J. L., Laffitte, A., Guyon, F., Bornet, F. R., \& Slama, G. (1996). Chronic consumption of short-chain fructooligosaccharides by healthy subjects decreased basal hepatic glucose production but had no effect on insulin-stimulated glucose metabolism. The American Journal of Clinical Nutrition, 63(6), 939-945. http://dx.doi.org/10.1093/ ajcn/63.6.939. PMid:8644690.

Megazyme International Ireland Ltda. (2018). Retrieved from https:// www.megazyme.com/documents/Booklet/K-FRUCHK_DATA.pdf

Nakamura, Y. K., \& Omaye, S. T. (2012). Metabolic diseases and proand prebiotics: mechanistic insights. Nutrition \& Metabolism, 9(1), 60-77. http://dx.doi.org/10.1186/1743-7075-9-60. PMid:22713169.

Nilsson, A. C., Ostman, E. M., Holst, J. J., \& Björck, I. M. (2008). Including indigestible carbohydrates in the evening meal of healthy subjects improves glucose tolerance, lowers inflammatory markers, and increases satiety after a subsequent standardized breakfast. The Journal of Nutrition, 138(4), 732-739. http://dx.doi.org/10.1093/ jn/138.4.732. PMid:18356328.
Ojansivu, I., Ferreira, C., \& Salminen, S. (2011). Yacon, a new source of prebiotic oligosaccharides with a history of safe use. Trends in Food Science \& Technology, 22(1), 40-46. http://dx.doi.org/10.1016/j. tifs.2010.11.005.

Parnell, J. A., \& Reimer, R. A. (2012). Prebiotic fiber modulation of the gut microbiota improves risk factors for obesity and the metabolic syndrome. Gut Microbes, 3(1), 29-34. http://dx.doi.org/10.4161/ gmic.19246. PMid:22555633.

Randomization. (2017). Retrieved from http://www.randomization.com

Russo, F., Chimienti, G., Riezzo, G., Pepe, G., Petrosillo, G., Chiloiro, M., \& Marconi, E. (2008). Inulin-enriched pasta affects lipid profile and $\mathrm{Lp}$ (a) concentrations in Italian young healthy male volunteers. European Journal of Nutrition, 47(8), 453-459. http://dx.doi. org/10.1007/s00394-008-0748-1. PMid:18853230.

Russo, F., Riezzo, G., Chiloiro, M., De Michele, G., Chimienti, G., Marconi, E., D’attoma, B., Linsalata, M., \& Clemente, C. (2010). Metabolic effects of a diet with inulin-enriched pasta in healthy young volunteers. Current Pharmaceutical Design, 16(7), 825-831. http://dx.doi.org/10.2174/138161210790883570. PMid:20388093.

Scheid, M. M., Genaro, P. S., Moreno, Y. M., \& Pastore, G. M. (2014). Freeze-dried powdered yacon: effects of FOS on serum glucose, lipids and intestinal transit in the elderly. European Journal of Nutrition, 53(7), 1457-1464. http://dx.doi.org/10.1007/s00394-013-0648-x. PMid:24398786.

Silva, M. F. G., Dionísio, A. P., Abreu, F. A. P., Brito, E. S., Wurlitzer, N. J., Silva, L. M. A., Ribeiro, P. R. V., Rodrigues, S., Taniguchi, C. A. K., \& Pontes, D. F. (2018b). Evaluation of nutritional and chemical composition of yacon syrup using $1 \mathrm{H}$ NMR and UPLC-ESI-Q-TOFMS E. Food Chemistry, 245, 1239-1247. http://dx.doi.org/10.1016/j. foodchem.2017.11.092. PMid:29287348.

Silva, M. F. G., Dionísio, A. P., Abreu, F. A. P., Pinto, C. O., Silva, L. M. A., Brito, E. S., Wurlitzer, N. J., Lima, A. C. V., Rodrigues, S., Gomes, W. F., \& Pontes, D. F. (2018a). Optimization of enzymatic treatment to produce yacon juice clarified by microfiltration with high levels of chlorogenic acid and fructooligosaccharides. Journal of Food Processing and Preservation, 42(6), e13641. http://dx.doi. org/10.1111/jfpp.13641.

Silva, M. F. G., Dionísio, A. P., Carioca, A. A. F., Silveira, A. L., Pinto, C. O., Abreu, F. A. P., Wurlitzer, N. J., Araújo, I. M., Garruti, D. S., \& Pontes, D. F. (2017). Yacon syrup: food applications and impact on satiety in healthy volunteers. Food Research International, 100(Pt 1), 460-467. http://dx.doi.org/10.1016/j.foodres.2017.07.035. PMid:28873709.

Sperry, M. F., Silva, H. L. A., Balthazar, C. F., Esmerino, E. A., Verruck, S., Prudencio, E. S., Neto, R. P. C., Tavares, M. I. B., Peixoto, J. C., Nazzaro, F., Rocha, R. S., Moraes, J., Gomes, A. S. G., Raices, R. S. L., Silva, M. C., Granato, D., Pimentel, T. C., Freitas, M. Q., \& Cruz, A. G. (2018). Probiotic Minas Frescal cheese added with L. casei 01: Physicochemical and bioactivity characterization and effects on hematological/biochemical parameters of hypertensive overweighted women: a randomized double-blind pilot trial. Journal of Functional Foods, 45, 435-443. http://dx.doi.org/10.1016/j.jff.2018.04.015.

Teimouri, S., Abbasi, S., \& Scanlon, M. G. (2018). Stabilisation mechanism of various inulins and hydrocolloids: milk-sour cherry juice mixture. International Journal of Food Technology, 71(1), 208-215. http:// dx.doi.org/10.1111/1471-0307.12376.

Utzschneider, K. M., Kratz, M., Damman, C. J., \& Hullar, M. (2016). Mechanisms linking the gut microbiome and glucose metabolism. The Journal of Clinical Endocrinology and Metabolism, 101(4), 1445-1454. http://dx.doi.org/10.1210/jc.2015-4251. PMid:26938201. 
Van Dokkum, W., Wezendonk, B., Srikumar, T. S., \& Van Den Heuvel, E. G. (1999). Effect of nondigestible oligosaccharides on largebowel functions, blood lipid concentrations and glucose absorption in young healthy male subjects. European Journal of Clinical Nutrition, 53(1), 1-7. http://dx.doi.org/10.1038/sj.ejcn.1600668. PMid:10048793.

Wanders, A. J., Van den Borne, J. J., de Graaf, C., Hulshof, T., Jonathan, M. C., Kristensen, M., Mars, M., Schols, H. A., \& Feskens, E. J. (2011). Effects of dietary fibre on subjective appetite, energy intake and body weight: a systematic review of randomized controlled trials.
Obesity Reviews, 12(9), 724-739. http://dx.doi.org/10.1111/j.1467789X.2011.00895.x. PMid:21676152.

Williams, C. M., \& Jackson, K. G. (2002). Inulin and oligofructose: effects on lipid metabolism from human studies. British Journal of Nutrition, 87(Suppl. 2), S261-S264. http://dx.doi.org/10.1079/ BJN/2002546. PMid:12088527.

Yamashita, K., Kawai, K., \& Itakura, M. (1984). Effects of fructooligosaccharides on blood-glucose and serum lipids in diabetic subjects. Nutrition Research, 4(6), 961-966. http://dx.doi. org/10.1016/S0271-5317(84)80075-5. 